worked examples figure in the text, for surely it is only by such means that a reader can make certain that he understands how to apply the theory, however seemingly perfectly and extensively he may be able to reproduce it. The book can be unhesitatingly recommended to allstudent, teacher, research-worker, professors, and othersand in the hope that a second edition is called for soon perhaps Mr. Pars could meanwhile collect and supply some examples further to enhance the value of this remarkable book.

R. A. LytTleton

\section{THE BRITISH ISLES}

Field Studies in the British Isles

Edited by Prof. J. A. Steers. Pp. xxiii +528. (London: Thomas Nelson and Sons, Ltd., 1964.) 70s. net.

The British Isles

A Systematic Geography. Edited by Prof. J. Wreford Watson and Dr. J. B. Sissons. Pp. xiit 452. (London: Thomas Nelson and Sons, Ltd., 1964.) 45s. net.

WHEN the twentieth International Geographical Congress was held in the United Kingdom during July-August 1964 and attended by some 2,200 delegates, it followed the pattern laid down by the preceding Congress held in the five countries of Norden in 1960. The week of main meetings, opened by Her Majesty The Queen, accompanied by His Royal Highness Prince Philip, in the Albert Hall on July 21, was preceded and followed by specialist symposia in different parts of the United Kingdom. In this way every university and many other institutions in the country had an opportunity of playing a part. There were no less than 33 such symposia; some were essentially regional-msuch as the meetings in the Channel Isles, the Outer Hebrides, or Ulster-others concerned themselves with a definite topic, such as the agricultural geography of Ireland, the geomorphology of Snowdonia, or urban growth in Yorkshire and Lancashire, while still others were wide-ranging, such as geography in the National Parks, or the eight-day study tours of Ireland and Scotland.

Field Studies is a substantial well-produced volume of 528 pages, fully illustrated with maps and diagrams, which provides the essential background material to these symposia and study tours. Whereas previous Congresses have issued 'excursion guides' of a more or less ephemeral nature, this volume has both a permanent and topical value not only because it affords regional descriptions by the experts on the spot, but also because the itineraries followed could scarcely be bettered by anyone wishing to see on the ground the various aspects of Britain's geography. There is one chapter only on London, but the varied aspects of London's geography, seen by many during the main Congress, are covered in Guide to London Excursions, edited by $K$. M. Clayton (obtainable from the London School of Economics, 21s.).

All full members of the Congress were also presented with a volume of Abstract Papers (with supplement) edited by F. E. Ian Hamilton (now obtainable from Geographical Publications, Bude. 7s.) and in due course will receive the Proceedings, but they also received on registration The British Isles, a finely produced volume to which 23 leading British geographers have contributed. Among the standard works already in existence, The British Isles, by L. D. Stamp and S. H. Beaver, now in its fifth edition (Longmans, 1963), covers in sequence the varied aspects of the geography of the British Isles, and Great Britain: Geographical Essays, edited by Jean Mitchell (Cambridge, 1962), deals with the country by regions. Consequently, the Editorial Committe felt that the Congress volume should take up topics in sequence. Thus, the senior editor contributes a first chapter on the "Individuality of Britain" and is followed by R. W. Steel on "British Geographers", G. R. Crone on the "Mapping of
Britain", S. Gregory on "Climate", W. G. V. Balchin on "Hydrology", and so on. While there are chapters which cover the usual-such as "Relief and Structure" (G. T. Warwick) or "Agriculture" (W. R. Mead)-all have a freshness of approach and presentation; other contributions reflect new and developing aspects of study, such as Emrys Jones on "Cultural Geography".

Modern geographers commonly accept that their study is essentially that of the relation between man and his environment, a relationship which has undergone a complex evolution through the ages and which projects itself into the future in the realm of physical planning. Those geographers who concern themselves with the physical background, whether the relief of the land or the vagaries of climate, have become increasingly aware of the importance of minutiae. This is well brought out in the three chapters: "Tertiary Landscape Evolution" (D. L. Linton), "The Glacial Epoch" (J. B. Sissons) and "The Evolution of the Climatic Environment" (G. Manley). The essays which follow are nearly all heavily weighted on the historical side-from prehistoric (E. E. Evans), preand post-industrial revolution (H. C. Darby and $R$. Lawton) to the present-day problems of land use (J. W. Birch and J. T. Coppock) or the mineral industry (S. H. Beaver) and industry (E. M. Rawston).

As with all such collections of essays, the specialists expand on their own interests-A. E. Smailes on towns, A. C. O'Dell on transportation, H. Thorpe on rural settlement, and R. H. Osborne on population, but, thanks to skilful editing, obvious gaps are few.

The Congress has thus made a notable contribution to geographical thought: it has adequately supplemented, rather than replaced, existing works, and Britain is now well served by the range of books available.

\section{Dudley Stamp}

\section{THE FUNGI}

\section{Die Pilze}

Grundzüge ihrer Entwicklungsgeschichte und Morphologie. Zweite, umgearbeitete und erweiterte Auflage. Von Prof. E. Gaümann. (Reihe der Experimentellen Biologie, Band IV.) Pp. 541. (Basel und Stuttgart: Birkhäuser Verlag, 1964.) $66 \mathrm{Sw}$. franes.

7 HIS is the second edition of Die Pilze, first published in 1949 and translated into English by Wynd in 1952. The second edition is some 120 pages longer than the first and contains 170 more illustrations. In content the book is modelled closely on its predecessor, but there has been considerable revision of the classification of Ascomycetes. The emphasis throughout is on morphology and life-cycles. Attempts to interpret the probable course of evolution to elucidate phylogenetic relationships are frequently represented in the form of phylogenetic trees. The evidence of such interrelationships is often very slight, and although the suggested relationships are qualified as conjectural, there is a danger that they will become accepted as established.

Apart from the notable omission of the Fungi Imperfecti, dismissed in little more than a page, and the lichens, most groups of fungi have been dealt with. The classification of the 'Phycomycetes' does not reflcct recent thinking (see, for example, the work of Sparrow), and the group Archimycetes is retained for holocarpic zoosporic forms. This has the unfortunate effect of separating Olpidium and Synchytrium from the Chytridiales. The Saprolegniaceae, Peronosporaceae and Leptomitaceae are treated as fam: lies of the Oomycetes, while the Mucoraceae, Encogonaceae and Entomophthoraceae are treated as families of the Zygomycetes, instead of being accorded original rank.

The classification of Ascomycetes has been radically revised, with the structure of the ascus wall emphasized as a primary criterion of separation. Three sub-classes 